\title{
Interrelationship between the growth-promoting effect of fish solubles and the gut flora of the chick
}

\author{
By G. F. HARRISON AND MARIE E. COATES \\ National Institute for Research in Dairying, Shinfleld, Reading RG2 $9 A T$ \\ (Received 17 September, I971 - Accepted 3 February 1972)
}

\begin{abstract}
I. The effect of dietary fish solubles on the growth and gut weight of conventional and germ-free chicks and of chicks given potentially growth-depressing agents present in the excreta was investigated.

2. Fish solubles significantly increased the growth of conventional but not of germ-free chicks. Oral administration of fresh, but not autoclaved, droppings depressed the growth of chicks hatched germ-free. Fish solubles partly overcame the depression due to fresh droppings.

3. Streptococcus faecalis or a bacteria-free filtrate prepared from chick droppings did not depress growth when given singly but did when given together. The depression in growth was entirely prevented by fish solubles.

4. Compared with germ-free chicks, the small intestine was heavier in conventional chicks and in those given fresh but not autoclaved droppings. A bacteria-free filtrate also increased the gut weight; Strep. faecalis had the opposite effect. When they were given together the gut weight was not different from that of germ-free chicks.
\end{abstract}

The presence of unidentified growth factors in materials such as fish solubles, distillers' dried solubles and dried whey has been postulated for many years. Fish solubles are produced from herring and other oily fish during the manufacture of fish meal. The fish are heated in steam to separate the oil and are then pressed. The liquid so removed is concentrated to a syrup of $40-50 \%$ total solids and about $30 \%$ crude protein. It is now generally accepted that fish solubles contain at least one factor which may, under certain conditions, improve the growth of chicks given a nutritionally adequate diet. Nevertheless, considerable variations in growth response within laboratories have been reported (Barnett \& Bird, 1956; Steinke, Bird \& Strong, I963; Harrison \& Coates, I964). The variations in growth response and their similarity to those observed in concurrent experiments with antibiotic supplements (Barnett \& Bird, 1956; Harrison \& Coates, 1964) led to the suggestion by these groups that the growth-promoting action of fish solubles may depend partly on modification of the intestinal microflora. Later, Harrison \& Coates (1969), in a preliminary report, showed that germ-free chicks grew only slightly better with than without dietary fish solubles, whereas their conventional counterparts exhibited a highly significant response to the supplement. 'They also observed that growth was depressed when chicks hatched germ-free were given fresh droppings obtained from conventional birds. The depression was only partly overcome when the chicks received a diet containing fish solubles.

Further experiments have now been completed in an attempt to characterize the components of the gut flora responsible for the growth depression counteracted by dietary fish solubles. It is well known that the small intestine of the antibiotic-fed chick is reduced in weight but not in length, and this gave rise to the suggestion that 
the thinner gut wall may permit more efficient utilization of nutrients and so lead to improved growth. As there was no evidence concerning the effect of fish solubles on the gut of the chick, it was important to establish whether its effect on growth came about as a result of changes in the small intestine. Therefore, in some experiments the weight and length of the small intestine were measured. The lengths did not differ significantly, hence these values are not reported.

\section{EXPERIMENTAL}

Chicks

Clean eggs were obtained from a breeding flock of Rhode Island Red cocks and Light Sussex hens kept on Institute premises. On the igth day of incubation the shells were disinfected either with mercuric chloride or with peracetic acid as described by Harrison (I969). Half the eggs were then taken into the germ-free isolators and half returned to the conventional incubator to hatch.

When hatching was completed the chicks were weighed and distributed to provide four birds in each cage. Because the number of chicks that can be housed in a germfree isolator is necessarily small, great care was taken in their selection. Cage mean weights were arranged to be as nearly as possible the same between isolators and between the germ-free and conventional environments. The sexes, distinguished by down colour, were also distributed equally in each cage. Chicks were wing-banded and individually weighed at weekly intervals for 4 weeks.

\section{Housing}

For most experiments Gustafsson isolators of the type described by Coates, Fuller, Harrison, Lev \& Suffolk (1963) were used for germ-free chicks. These contained two cages holding up to four chicks each. In a few experiments large units containing up to six cages were used. Conventional control groups were housed in a room whose temperature and humidity could be controlled to those of the isolators. The room was adequately ventilated with air drawn from outside, and no attempt was made to establish a level of hygiene above that normally obtained. Cages and feeding-troughs were similar to those inside the isolators.

\section{Diet and water}

For all experiments a vegetable-protein diet was used, composed of $(\%)$ : maize $37 \cdot 8$, barley 20 , defatted soya-bean meal 35 , dried grass 3 , bone meal ${ }^{\circ} 5$, limestone $\mathrm{I}$, $\mathrm{NaCl} 0.672, \mathrm{MnSO}_{4} .4 \mathrm{H}_{2} \mathrm{O} 0.028$, maize oil (containing $\mathrm{I} \cdot 6 \mu \mathrm{g}$ cholecalciferol $/ \mathrm{g}$ ) I. The diet was supplemented with 680 i.u. retinol (Rovimix A 325 ; Roche Products, Welwyn Garden City) $/ \mathrm{kg}$ and with $(\mathrm{mg} / \mathrm{kg}$ ): biotin 0.22 , pteroylmonoglutamic acid 0.83 , thiamin 3.3 , pyridoxal 4.4 , riboflavin 7.7 , calcium pantothenate 16.5 , nicotinic acid 55 , cyanocobalamin 0.02 . The sample of fish solubles was of Norwegian origin and was representative of good-quality condensed herring solubles as commercially available. It was added to the diet at the rate of $5 \%(\mathrm{w} / \mathrm{w})$. For sterilization, the diets were packed into plastic bags and irradiated at $5 \mathrm{Mrad}$ from a ${ }^{60} \mathrm{Co}$ source at the Wan- 
tage Research Laboratory. The germ-free and conventional chicks had free access to the diet and water. Sterilized drinking-water was supplied inside the isolators; conventional birds received ordinary tap-water.

\section{Tests for sterility}

Tests were done at weekly intervals, the last being on the day before the experiment finished. The method was essentially that described by Fuller (r968). Only those isolators that remained germ-free for 4 weeks or that contained only the organism that had been introduced were used to supply values for statistical analysis.

\section{Plan of experiments}

In all experiments one-half of the chicks in each isolator were given the basal diet, the other half were given the diet supplemented with fish solubles.

\section{Expt I}

The effect of fish solubles on the growth and small intestine weight of germ-free chicks was compared with that of conventional chicks kept in the temperaturecontrolled room.

Expt 2

Germ-free chicks were dosed with droppings from conventional birds to see whether a fish-solubles-relieved growth depression could be achieved similar to that in conventional quarters. Autoclaved droppings were given to some groups to serve as controls.

Untreated droppings. Droppings voided over a period of $3^{-4} \mathrm{~d}$ were collected from 2-week-old chicks that had been given the unsupplemented diet in a conventional animal room. About $50 \mathrm{~g}$ were mixed with sufficient distilled water in a laboratory blender to form a homogeneous paste. This was distributed into screw-capped bottles which were disinfected on the exterior by immersion in $70 \%$ ethanol for 30 min to reduce the risk of contamination by extraneous organisms and then passed into the isolators. About $0.5 \mathrm{~g}$ droppings were given on a spatula to each chick before the birds were allowed access to the diets.

Autoclaved droppings. Droppings collected as described above were blended with about four times their weight of distilled water and poured into screw-capped bottles. These were placed in nylon-film bags and autoclaved for $30 \mathrm{~min}$ at $\mathrm{I} 2 \mathrm{I}^{\circ}$. When cool, the bottle was taken from the bag by an operator wearing sterilized gloves and was passed into the isolator via the dunk tank. Because it was impracticable to dose the chicks with material of this consistency, the equivalent of about I $g$ per chick was spread on the diet.

\section{Expt 3}

It seemed possible that the observed growth-depressing effect of fresh droppings may have been caused by a viable but non-bacterial component such as a virus. To examine this possibility, a bacteria-free filtrate was prepared from the droppings of conventional chicks and was administered to germ-free chicks. 
Bacteria-free filtrate. Droppings voided over a period of $3-4 \mathrm{~d}$ by conventional chicks consuming the unsupplemented diet were mixed with twice their weight of distilled water in a laboratory blender. The resultant slurry was first centrifuged at $680 \mathrm{~g}$ for $40 \mathrm{~min}$ at $5^{\circ}$, then the supernatant fraction was centrifuged at ${ }^{6} 6500 \mathrm{~g}$ for $30 \mathrm{~min}$ at $5^{\circ}$. The clear liquid was filtered through a Seitz filter into a Buchner flask and then aseptically introduced via rubber tubing into a germ-free isolator. The fluid was collected in small screw-capped bottles and all but the one required in that isolator were double-wrapped in nylon-film bags and taken out for transfer to other isolators. Chicks were dosed by mouth on the day of hatching with $0.2 \mathrm{ml}$ filtrate by means of a hypodermic syringe fitted with a round-ended needle.

\section{Expt 4}

A strain of Streptococcus commonly found in the chick gut was tested for growthdepressing activity with and without the bacteria-free filtrate.

Streptococcus faecalis var. liquefaciens. This strain ( $\mathrm{LC}_{5} \mathrm{M}$ ) was isolated and characterized by Fuller \& Jayne-Williams (I 970 ), who recovered it from the liver of a 5 -d-old chick. Subsequent tests showed it to be capable of translocating from the gut to the liver and it was assumed therefore to have originated in the intestinal tract. It was chosen for use in these experiments because it appeared to be potentially one of the more harmful of the gut streptococci. The organism was grown overnight at $37^{\circ}$ in Yeastrel (Mapleton's Food Ltd, Garston, Liverpool I9) glucose broth in glass ampoules. These were then sealed and when required were disinfected by immersion for $30 \mathrm{~min}$ in a $2 \%(\mathrm{v} / \mathrm{v})$ solution of peracetic acid with $0.2 \%(\mathrm{v} / \mathrm{v})$ Lissapol (ICl, Millbank, London SWI) as a spreading agent. They were taken into the isolators via the dunk tank and $0.2 \mathrm{ml}$ was administered to the chicks on the day of hatching. In some experiments chicks were dosed with the Strep. faecalis culture and the filtrate. The establishment of the Streptococcus in the gut was confirmed by making counts of viable organisms, on Yeastrel glucose agar, of the contents of the crop, ileum and caecum.

\section{RESULTS}

It is immediately apparent (Table $x$ ) that chicks given the basal diet grew less well in conventional quarters than they did in a germ-free environment. The supplement of fish solubles increased the level of growth of conventional chicks to that of their germ-free counterparts. Dietary fish solubles caused only a small non-significant growth increase in germ-free birds.

The intestines were significantly heavier in conventional than in germ-free chicks whether or not fish solubles was added to the diet. The reducing effect of fish solubles on the gut weight of germ-free chicks just reached significance and on that of conventional chicks just failed to reach significance.

Untreated droppings brought about a significant reduction in body-weight, as compared with that of germ-free chicks, whereas autoclaved droppings did not (Table 2). Fish solubles increased the level of growth of chicks receiving autoclaved droppings to that of germ-free birds but only partly overcame the severe depression caused by untreated droppings. 
Table I. Expt 1. Effect of fish solubles on the growth and small intestine weight of germ-free and conventional chicks

(Number of groups of four chicks in parentheses)

\begin{tabular}{llcr} 
& \multicolumn{3}{c}{ Mean body-wt (g) } \\
\cline { 2 - 4 } & Germ-free & Conventional & Mean \\
Without fish solubles & $336 \cdot 8(22)$ & $303 \cdot 3(\mathbf{2 2})$ & $320 \cdot 1$ \\
With fish solubles & $350 \cdot 3(22)$ & $340 \cdot 1(22)$ & $345 \cdot 2$ \\
General mean & $343 \cdot 6$ & $321 \cdot 7$ & $332 \cdot 7$
\end{tabular}

$\mathrm{SE}$ of a diet or an environment mean $=4.33(84 \mathrm{df})$.

$\mathrm{SE}$ of a diet $\times$ environment mean $=6 \cdot 12$.

Without fish solubles

With fish solubles

General mean
Mean gut wt (mg/g body-wt)

$\begin{array}{lll}30 \cdot 3(5) & 37 \cdot 3(5) & 33 \cdot 8 \\ 27 \cdot 9(5) & 35 \cdot 9(5) & 31 \cdot 9 \\ 29 \cdot 1 & 36 \cdot 6 & 32 \cdot 9\end{array}$

SE of a diet or an environment mean $=0.52(\mathrm{r} 6 \mathrm{df})$.

$\mathrm{SE}$ of a diet $\times$ environment mean $=0.74$.

Table 2. Expt 2. Effect of fish solubles on the growth and small intestine weight of chicks hatched germ-free and given untreated or autoclaved droppings from conventional chicks

(Number of groups of four chicks in parentheses)

\begin{tabular}{lcccc} 
& \multicolumn{4}{c}{ Mean body-wt (g) } \\
\cline { 2 - 5 } & Germ-free & $\begin{array}{c}\text { Untreated } \\
\text { droppings }\end{array}$ & $\begin{array}{c}\text { Autoclaved } \\
\text { droppings }\end{array}$ & Mean \pm SEM \\
Without fish solubles & $352 \cdot 8(6)$ & $283 \cdot 2(5)$ & $337 \cdot 7(6)$ & $324 \cdot 6 \pm 5 \cdot 26$ \\
With fish solubles & $373 \cdot 0(6)$ & $312 \cdot 8(6)$ & $369 \cdot 0(6)$ & $351 \cdot 6 \pm 5 \cdot 09$ \\
General mean & $362 \cdot 9$ & $298 \cdot 0$ & $353 \cdot 4$ & $338 \cdot 1$ \\
SEM (29 df) & $6 \cdot 32$ & $6 \cdot 55$ & $6 \cdot 32$ & -
\end{tabular}

$\mathrm{SE}$ of a diet $\times$ environment mean $=8.82$ ( 6 groups); 9.67 (5 groups).

(No. of chicks in parentheses)

\begin{tabular}{lllll} 
& \multicolumn{3}{c}{ Mean gut wt (mg/g body-wt) } \\
\cline { 2 - 4 } Without fish solubles & - & $36 \cdot 2(7)$ & $28 \cdot 0(7)$ & $32 \cdot 1$ \\
With fish solubles & - & $35 \cdot 6(7)$ & $27 \cdot 8(7)$ & $31 \cdot 7$ \\
$\quad$ General mean & - & $35 \cdot 9$ & $27 \cdot 9$ & $3 \times \cdot 9$
\end{tabular}

SE of a diet or an environment mean $=0.87(24 \mathrm{df})$.

$\mathrm{SE}$ of a diet $X$ environment mean $=\mathrm{I} \cdot 22$.

When chicks hatched germ-free were dosed with fresh droppings the weight of the small intestine was increased as compared with that of chicks dosed with autoclaved droppings. The effect of fish solubles in both instances was small and non-significant.

Table 3 shows that the growth of chicks given a single dose of the bacteria-free filtrate was not different from that of undosed chicks, nor did dietary fish solubles significantly improve the growth of chicks in either instance. 
Table 3. Expt 3 . Effect of fish solubles on the growth and small intestine weight of chicks hatched germ-free and given or not given a bacteria-free filtrate from conventional chick droppings

(Number of groups of four chicks in parentheses)

\begin{tabular}{lccc} 
& \multicolumn{3}{c}{ Mean body-wt (g) } \\
\cline { 2 - 4 } Without filtrate & With filtrate & Mean \pm sEM \\
Without fish solubles & $\mathbf{3 2 2} \cdot 8(8)$ & $321 \cdot \mathrm{I}(7)$ & $322 \cdot 0 \pm 6 \cdot 52$ \\
With fish solubles & $334 \cdot 3(8)$ & $337 \cdot 1(7)$ & $335 \cdot 7 \pm 6 \cdot 52$ \\
General mean & $328 \cdot 6$ & $329 \cdot 1$ & $328 \cdot 9$ \\
SEM (26 df) & $6 \cdot 29$ & $6 \cdot 73$ & -
\end{tabular}

SE of a diet $\times$ environment mean $=8 \cdot 90(8$ groups $) ; 9.52(7$ groups $)$.

\begin{tabular}{llll} 
& \multicolumn{3}{c}{ Mean gut wt (mg/g body-wt) } \\
\cline { 2 - 4 } Without fish solubles & $29 \cdot 7(6)$ & $32 \cdot 6(4)$ & $31 \cdot 2 \pm 0 \cdot 34$ \\
With fish solubles & $27 \cdot 6(6)$ & $30 \cdot 2(4)$ & $28 \cdot 9 \pm 0 \cdot 34$ \\
General mean & $28 \cdot 7$ & $31 \cdot 4$ & $30 \cdot 1$ \\
SEM (I6 df) & $0 \cdot 30$ & 0.37 & -
\end{tabular}

SE of a diet $\times$ environment mean $=0.43$ ( 6 groups) $; 0.52$ (4 groups).

Table 4. Expt 4. Effect of fish solubles on the growth and small intestine weight of chicks monoassociated with Streptococcus faecalis and given or not given a bacteria-free filtrate

(Number of groups of four chicks in parentheses)

$\begin{array}{lcccc}\text { Germ-free } & \text { Strep. faecalis } & \begin{array}{c}\text { Strep. faecalis } \\ \text { filtrate }\end{array} & \text { Mean } \pm \text { sEM } \\ \text { Without fish solubles } & 326 \cdot 3(3) & 314 \cdot 8(4) & 300 \cdot 8(4) & 314 \cdot 0 \pm 3 \cdot 84 \\ \text { With fish solubles } & 335 \cdot 0(3) & 341 \cdot 3(4) & 329 \cdot 3(4) & 335 \cdot 2 \pm 3 \cdot 84 \\ \text { General mean } & 330 \cdot 7 & 328 \cdot 1 & 315 \cdot 1 & 324 \cdot 6 \\ \text { SEM (I6 df) } & 5 \cdot 16 & 4 \cdot 46 & 4 \cdot 46 & -\end{array}$

SE of a diet $\times$ environment mean $=6 \cdot 3$ ( 4 groups $) ; 7 \cdot 3$ ( 3 groups).

\begin{tabular}{lllll} 
& \multicolumn{4}{c}{ Mean gut wt (mg/g body-wt) } \\
Without fish solubles & $28.2(3)$ & $23.7(4)$ & $28.6(4)$ & $26.8 \pm 0.5 \mathrm{I}$ \\
With fish solubles & $26.5(3)$ & $23.9(4)$ & $26.6(4)$ & $25.7 \pm 0.5 \mathrm{I}$ \\
General mean & 27.4 & 23.8 & 27.6 & 26.3 \\
SEM (I6 df) & 0.69 & 0.60 & 0.60 & -
\end{tabular}

SE of a diet $\times$ environment mean $=0.84$ ( 4 groups $) ; 0.97$ ( 3 groups).

The gut weight of chicks dosed with the bacteria-free filtrate was significantly heavier than that of chicks not so dosed. Dietary fish solubles reduced the gut weight whether or not the chicks were dosed with the filtrate.

Monoassociation of germ-free chicks with Strep. faecalis depressed their growth to a small extent; when the organism was administered with the bacteria-free filtrate growth was markedly depressed (Table 4 ). This depression in growth was entirely overcome by fish solubles. 
Table 5. Viable counts of Streptococcus faecalis in the tract of gnotobiotic chicks

\begin{tabular}{|c|c|c|c|c|}
\hline \multirow[b]{2}{*}{ Diet } & \multirow[b]{2}{*}{ Organisms added } & \multicolumn{3}{|c|}{$\log _{10}$ no. of streptococci/organ } \\
\hline & & Crop & Ileum & Caecum \\
\hline Basal & Streptococcus & $8 \cdot 0^{*}$ & $7 \cdot 9$ & 9.5 \\
\hline Fish solubles & Streptococcus & $7 \cdot 6$ & $7 \cdot 8$ & $9 \cdot 4$ \\
\hline Basal & $\begin{array}{l}\text { Streptococcus + bacteria- } \\
\text { free filtrate }\end{array}$ & $8 \cdot 0$ & $8 \cdot 0$ & $9 \cdot 8$ \\
\hline Fish solubles & $\begin{array}{l}\text { Streptococcus + bacteria- } \\
\text { free filtrate }\end{array}$ & $7 \cdot 9$ & $8 \cdot 0$ & $10 \cdot I$ \\
\hline
\end{tabular}

Gut weight was significantly reduced by the organism alone, as compared with that of germ-free chicks or with those dosed with the filtrate plus the bacterial culture. Gut weights of the latter group were not different from those of germ-free control groups. In this experiment the addition of fish solubles to the diet did not significantly alter the gut weight of any groups.

'Table 5 shows the counts of the streptococci in the crop and intestine of chicks at the end of the 4-week experimental period. The organism established itself throughout the gut and the count was not markedly affected by any of the treatments.

\section{DISCUSSION}

The hypothesis submitted by Barnett \& Bird (1956) and by Harrison \& Coates ( 1964 ) that fish solubles may stimulate growth of the chick by modification of its intestinal microflora is strongly supported by these results. Although in every experiment in which fish solubles were included in the diet of germ-free chicks a small improvement in growth was observed, the response never attained the accepted level of statistical significance. Thus it can be concluded that a small part of the effect of fish solubles on chick growth is independent of the presence of micro-organisms, but the consistently greater response in the conventional environment implies that the main growth-promoting effect is mediated through the bird's associated microflora.

There have been several reports that the growth of germ-frce chicks is superior to that of their conventional counterparts (Forbes \& Park, 1959; Gordon \& BrucknerKardoss, 1959; Coates et al. 1963; Eyssen \& De Somer, 1967), and it seems likely that some component of the gut microflora prevents the bird from developing its full growth potential. Thus the severe depression in growth brought about by feeding chicks with untreated droppings was not unexpected, and the small quantity of material necessary to produce the depression lends support to the suggestion that a viable organism may have been responsible. Furthermore, autoclaved droppings failed to depress the growth of germ-free birds.

In each instance the dietary supplement of fish solubles significantly improved growth, although it did not fully reverse the severe depression caused by administration of the unheated droppings. The growth response brought about by dietary fish 
solubles in birds given autoclaved droppings was surprising and appears to conflict with the idea that fish solubles might be counteracting the effect of a living agent. However, it seems possible that the result was fortuitous. Although neither group exhibited significantly poorer growth than its germ-free counterpart, a small weightdepression in the unsupplemented birds combined with the usual small 'non-microbial' response to fish solubles gave a large enough difference between the two groups to pass the test for significance.

In earlier work in this laboratory, Powell (1967) also found that fresh droppings depressed the growth of chicks hatched germ-free. In his experiments, penicillin partly counteracted the depression. Harrison \& Coates (1964) showed that the growth-promoting effects of fish solubles and of penicillin were not interchangeable but additive, implying that two or more factors needed to be overcome before the bird could grow at its optimal rate. This idea is supported by the failure to counteract completely the depressed growth of chicks given fresh droppings either with fish solubles, in our experiments, or with penicillin in Powells' (1967) investigations. It remains to be determined whether or not the antibiotic and the fish solubles together could restore growth to that of the germ-free controls.

Our attempts to characterize the agent(s) responsible for the growth depression followed those of Eyssen \& De Somer ( 1967$)$, who examined a number of organisms isolated from the chick gut flora and also a bacteria-free filtrate prepared from chick gut contents. When they introduced into germ-free birds either the filtrate or a strain of Strep. faecalis alone, each caused a small reduction in weight; when both were given together a severe growth depression, only partly reversible with dietary antibiotics, occurred. In our experiments a bacteria-free filtrate prepared from the droppings of conventional chicks was without effect when given alone to germ-free birds, and our strain of Strep. faecalis caused only a very small depression in growth. However, the growth of the birds given both the filtrate and Streptococcus was markedly poorer than that of their germ-free controls. Their weights were restored to the germ-free level by a dietary supplement of fish solubles.

The mechanism of the growth depression is at present a matter for speculation. As Eyssen \& De Somer (1967) suggested, the filterable agent could be a virus, and its proliferation might damage the intestinal mucosa so as to permit secondary invasion by the bacterium. Mucosal damage might also be caused by a non-viable toxic substance in the filtrate. However, the possibility that the bacterium is the prime invader should not be overlooked. For example, Moore \& Gross (Ig68) showed in gnotobiotic turkeys that Strep. faecalis var. liquefaciens desquamated the intestinal wall, permitting penetration by a catenabacterium, with the subsequent development of liver granulomas. The mode of action of fish solubles is equally speculative. It did not affect the number of Strep. faecalis in the intestine, but an effect on the metabolism of the organism cannot be ruled out. An effect on the filterable agent is also possible.

The general experience in this laboratory and elsewhere is that the small intestine is heavier in conventional than in germ-free birds. Since the length is not significantly reduced, it is assumed that the conventional intestinal wall is thicker, a circumstance that might result in impaired absorption or utilization of nutrients and consequently 
lower growth rates. In the experiments reported here, the conventional birds and those given fresh droppings had heavicr small intestines than their germ-free counterparts. Birds given autoclaved droppings did not; hence the growth depression and increased gut weight appeared to be correlated. However, although the filtrate also brought about a small but significant increase in gut weight, the Strep. faecalis had the opposite effect. In neither instance was growth rate affected. When the two agents were given together the small intestine weights were not different from those for germ-free chicks yet in this instance growth was depressed. Fish solubles reduced gut weight in some experiments to a small extent, but the effect was not consistent. Thus these results reveal no clear-cut relationship between gut weight and the depression in growth or its reversal by fish solubles. Although the main growth-promoting effect of fish solubles has been shown to be mediated through the intestinal microflora of the chick, its mode of action has still to be elucidated.

We are grateful to Dr R. Fuller for supplying the Streptococcus and for helpful discussions, to Dr D. J. Jayne-Williams for sterility checks of the isolators and to Mr J. P. Fordham for care of the germ-free chicks.

\section{REFERENCES}

Barnett, B. D. \& Bird, H. R. (I956). Poult. Sci. 35, 705.

Coates, M. E., Fuller, R., Harrison, G. F., Lev, M. \& Suffolk, S. F. (rg63). Br. F. Nutr. r7, r4r.

Eyssen, H. \& De Somer, P. (1967). Poult. Sci. 46, 323 .

Forbes, M. \& Park, J. T. (1959). Y. Nutr. 67, 69.

Fuller, R. (I968). In The Germ-free Animal in Research p. 37 [M. E. Coates, editor]. London and New York: Academic Press.

Fuller, R. \& Jayne-Williams, D. J. (1970). Res, vet. Sci. rr, 368.

Gordon, H. A. \& Bruckner-Kardoss, E. (1959). Antibiotics $A$, r $95^{8-9}$ p. ro 2.

Harrison, G. F. (I 969). Lab. Anim. 3, 5 I.

Harrison, G. F. \& Coates, M. E. (r964). Br. F. Nutr. r8, 46r.

Harrison, G. F. \& Coates, M. E. (1969). Proc. Nutr. Soc. 28, 70 A.

Moore, W. E. C. \& Gross, W. B. (1968). Avian Dis. 12, 4 I7.

Powell, L. W. (1967). The significance of the gut flora of the chick and the rat. PhD Thesis, Reading University.

Steinke, F. H., Bird, H. R. \& Strong, F. M. (1963). 7. Nutr. 8o, 60. 